\title{
The first reported ceratopsid dinosaur from eastern North America (Owl Creek Formation, Upper Cretaceous, Mississippi, USA)
}

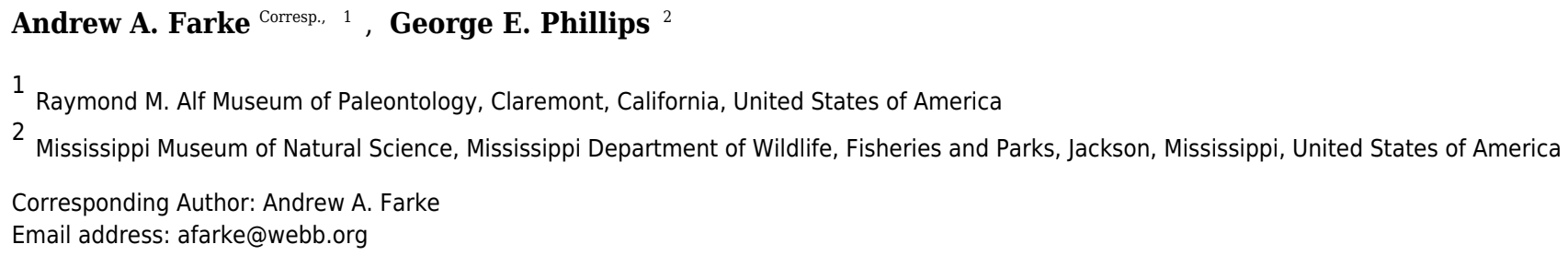

Ceratopsids ("horned dinosaurs") are known from western North America and Asia, a distribution reflecting an inferred subaerial link between the two landmasses during the Late Cretaceous. However, this clade was previously unknown from eastern North America, presumably due to limited outcrop of the appropriate age and depositional environment as well as the separation of eastern and western North America by the Western Interior Seaway during much of the Late Cretaceous. A dentary tooth from the Owl Creek Formation (late Maastrichtian) of Union County, Mississippi, represents the first reported occurrence of Ceratopsidae from eastern North America. This tooth shows a combination of features typical of Ceratopsidae, including a double root and a prominent, blade-like carina. Based on the age of the fossil, we hypothesize that it is consistent with a dispersal of ceratopsids into eastern North America during the very latest Cretaceous, presumably after the two halves of North America were reunited following the retreat of the Western Interior Seaway. 


\section{The first reported ceratopsid dinosaur from eastern North America (Owl Creek \\ 2 Formation, Upper Cretaceous, Mississippi, USA)}

3

4

5

Andrew A. Farke ${ }^{1}$ and George E. Phillips ${ }^{2}$

${ }^{1}$ Raymond M. Alf Museum of Paleontology, Claremont, California, USA

${ }^{2}$ Mississippi Museum of Natural Science, Mississippi Department of Wildlife, Fisheries and Parks, Jackson, Mississippi, USA

Corresponding Author:

Andrew A. Farke ${ }^{1}$

Email address: afarke@webb.org

\section{ABSTRACT}

Ceratopsids ("horned dinosaurs") are known from western North America and Asia, a distribution reflecting an inferred subaerial link between the two landmasses during the Late Cretaceous. However, this clade was previously unknown from eastern North America, presumably due to limited outcrop of the appropriate age and depositional environment as well as the separation of eastern and western North America by the Western Interior Seaway during much of the Late Cretaceous. A dentary tooth from the Owl Creek Formation (late Maastrichtian) of Union County, Mississippi, represents the first reported occurrence of Ceratopsidae from eastern North America. This tooth shows a combination of features typical of Ceratopsidae, including a double root and a prominent, blade-like carina. Based on the age of the fossil, we hypothesize that it is consistent with a dispersal of ceratopsids into eastern North America during the very latest Cretaceous, presumably after the two halves of North America were reunited following the retreat of the Western Interior Seaway.

\section{INTRODUCTION}

The Western Interior Seaway split North America during much of the Late Cretaceous, which in turn may have driven terrestrial faunal differences between eastern and western North America (Appalachia and Laramidia, respectively). Non-avian dinosaur fossils from the Late Cretaceous of Appalachia are, with a few notable exceptions, largely fragmentary and indicative of a fauna including theropods (ornithomimosaurs and tyrannosauroids), nodosaurids, hadrosauroids, and potentially leptoceratopsids (Schwimmer, 1997; Weishampel et al., 2004; Longrich, 2016; Prieto-Márquez, Erickson \& Ebersole, 2016a). The hadrosauroids and tyrannosauroids in particular have been suggested as representing clades distinct from their relatives in western North America (Longrich, 2016). This is further supported by the notable absence of ceratopsid dinosaurs, which are abundant in Laramidia, from the published fossil record of Appalachia. Faunal differences between Laramidia and Appalachia presumably were reduced when the two land masses rejoined following the retreat of the interior seaway during the late Maastrichtian (if they were indeed rejoined; see Slattery et al., 2015 for a discussion of this issue). Yet, late Maastrichtian fossils of terrestrial origin are virtually unknown from eastern North America, so there is little evidence to test this hypothesis.

Here, we report the first definitive ceratopsid specimen from eastern North America, a tooth recovered from the Maastrichtian Owl Creek Formation of Union County, Mississippi. The 
47 fossil, collected by the second writer (G. E. Phillips) in July 2016, suggests a dispersal of
48 ceratopsids into eastern North America following the regression of the Western Interior Seaway.

48

49

50

51

52

53

54

55

56

57

58

59

60

61

62

63

64

65

66

67

68

69

70

71

72

73

74

75

76

77

78

79

80

81

82

83

84

85

86

87

88

89

90

91

92

\section{GEOLOGIC SETTING Occurrence}

The tooth described here (MMNS VP-7969) was collected in loose association with the Upper Cretaceous marine Owl Creek Formation (and other units) in northeast Mississippi (Fig. 1). More precisely, it was found out of context in the active fluviatile lag of a modern stream, albeit probably in close proximity to its presumed stratigraphic origins. The pebbly, fossiliferous stream lag contains Pleistocene terrestrial-alluvial, Paleocene marine, and Cretaceous marine fossil float originating from the channel floor and (to a limited extent) the walls. The Paleocene is represented in the area by the Clayton Formation (Fig. 2), the nearest outcrop (preserving the base of the formation) of which is $\sim 4.3 \mathrm{~km}$ upstream (and up-section) from the tooth collection point. Fossil float originating from the Clayton Formation has been limited to fragments of the Paleocene index gastropod Kapalmerella mortoni (Conrad, 1830). Based on the extent of channel length explored thus far, Quaternary alluvium, slumping, vegetation, and water level conceal the underlying Owl Creek Formation (Upper Cretaceous) rather thoroughly, making direct access to the Owl Creek beds very difficult. Although rarely exposed in the stream, these beds crop out intermittently along the channel length between the base of the Clayton and the tooth recovery point. The tooth was retrieved from the stream float within a few meters of the contact between the Owl Creek Formation and the subjacent Chiwapa Sandstone Member of the Ripley Formation at MMNS locality MS.73.001b (Fig. 1).

Both the Cretaceous and Paleocene units cropping out in the channel contain marine vertebrate fossils, although vertebrate fossils are considerably more common in the former than in the latter. Cretaceous deposits in the area have previously produced dinosaur fossils, and the Paleocene occasionally contains reworked Upper Cretaceous fossils. Based on observations of several short-lived, partial exposures in the greater vicinity (e.g., MMNS locality MS.73.030), a persistent phosphatic fossil assemblage occurs in the uppermost part of the Owl Creek Formation. This assemblage consists largely of a shell bed of locally common, dark, welllithified phosphatic mollusk and decapod steinkerns along with less frequently occurring fragments of marine vertebrates - most of which are characteristically Maastrichtian (Fig. 3, Table 1; Baird, 1986; Phillips, Nyborg \& Vega, 2014; Martínez-Díaz et al., 2016). The upper Owl Creek steinkern assemblage is conspicuously populated by baculitid and scaphitid ammonites not seen elsewhere in the local Maastrichtian section. These same ammonites are common in the stream float that yielded the ceratopsian tooth. The Chiwapa Sandstone is very fossiliferous, as is the basal Owl Creek Formation. However, the suite of Cretaceous fossils in the float is generally inconsistent with the assemblage contained in either of these intervals. The Chiwapa contains crystalline calcite pseudomophs of mollusk shells, none of which are scaphitid or baculitid ammonites. Also, the highly lithified Chiwapa Sandstone does not surrender fossils to the stream bed in one piece - shark teeth, bones, and even shells shatter as soon as they begin weathering from the surface of the rocky exposure. Where the ceratopsian tooth was recovered, the basal Owl Creek is exposed and deeply weathered and contains mollusk steinkerns; however, it also lacks the kinds of ammonites consistent with the stream float. Of all the sourceable constituents of the modern stream lag, the ceratopsian tooth is most consistent with the average size, specific gravity, and color of the phosphatic fossils and pebbles that populate the upper part of the Owl Creek Formation. 
93

94

95

96

97

98

99

100

101

102

103

104

105

106

107

108

109

110

111

112

113

114

115

116

117

118

119

120

121

122

123

124

125

126

127

128

129

130

131

132

133

134

135

136

137

138

\section{The Owl Creek Formation}

The Owl Creek Formation crops out in portions of several states within the former Mississippi Embayment-Missouri, Illinois, Tennessee, and Mississippi (Fig. 1). Local thickness of the Owl Creek Formation is about $12 \mathrm{~m}$, and it is rich in Maastrichtian neritic marine fossils (Stephenson, 1955; Sohl, 1960; Sohl \& Koch, 1983, 1986). The Owl Creek Formation in northeast Mississippi is composed of glauconitic, variably micaceous, fine-grained beds ranging from sandy clay to clayey sand that become increasingly calcareous to the south where the mostly siliciclastic facies of Tippah and Union counties (including MMNS locality MS.73.001b) grade into the bedded marls and 'dirty chalk' of the Prairie Bluff Formation (Stephenson \& Monroe, 1940; Sohl, 1960). Thus, terrigenous input in this part of the outcrop belt decreases towards the more pelagic waters of the gulfward shelf. The Owl Creek sediments on the opposite side of the embayment in Missouri and at the head of the embayment in Illinois are texturally and compositionally similar. Likewise, the formation becomes decreasingly calcareous, and then entirely terrigenous, moving northward into the head of the embayment and nearer to the McNairy delta system.

In the first grand interpretation of Upper Cretaceous sedimentation in the Mississippi Embayment, the depositional sequence in the embayment proper was revealed to consist of sediments mineralogically derived from the Appalachian Plateaus and Blue Ridge Mountains (Pryor, 1960). In that study, the Owl Creek Formation was described as an inner prodelta facies of the McNairy Delta complex, although deposited on top of, and partially reworked from, the lower Maastrichtian McNairy Formation during the very last Cretaceous marine transgression into the embayment. In a sequence stratigraphic model, the lower contact of the Owl Creek with the McNairy Sand or Chiwapa Member of the Ripley Formation represents a transgressive surface. Subsequent beds in the Owl Creek would thus represent sediments associated with a transgressive systems tract followed by progradational beds of a highstand systems tract (Mancini et al., 1995).

A palynomorph assemblage from the Owl Creek Formation across the embayment in Missouri suggests an inner neritic marine environment with high terrestrial input (Eifert, 2010). Angiosperms (Betulaceae, Juglandaceae, Oleaceae, Fagaceae, and Nyssaceae) dominate the assemblage, followed by palm (Areaceae) and cycads (Cycadaceae). A foraminiferal suite from the same samples indicates a hypersaline marsh, and a low-diversity/low-abundance dinoflagellate assemblage is inconsistent with a highstand systems tract (Mancini et al., 1995; Eifert, 2009).

\section{Taphonomy}

The discovery of dinosaur remains in marine environments occurs infrequently and typically consists of isolated elements or, more rarely, larger skeletal portions (e.g. partial limb or vertebral associations) shed from a bloat-and-float carcass (Schäfer, 1972; Schwimmer, 1997). In this scenario, the buoyant carcasses of coastal dinosaurs, particularly those originating in riparian habitats of tide-dominated estuaries and deltas, are carried to sea by seasonal or episodic freshets and tides. Dinosaur remains from more distal shelf deposits, particularly the more complete skeletal associations, may result from transport enhanced by maritime storms, such as tropical cyclones. Dinosaur fossils in marine sediments seem to be more commonly encountered, and possess greater taxonomic diversity, as fragmentary yet identifiable bones and teeth from nearshore lag deposits (Schwimmer, 1997). 
139

140

141

142

143

144

145

146

147

148

149

150

151

152

153

154

155

156

157

158

159

160

161

162

163

164

165

166

167

168

169

170

171

172

173

174

175

176

177

178

179

180

181

182

183

184

In addition to being the first dinosaur tooth documented from the Owl Creek Formation, the ceratopsian tooth is the first terrestrial macrofossil ever reported from this unit-muchstudied previously for its marine macroinvertebrate content. Although characteristically rich in neritic fossils, the aforementioned terrigenous microfossils suggest a not too distant shoreline (Eifert, 2009). Thus, the occurrence in the Owl Creek of a dinosaur fossil, although rare, is not entirely unexpected.

Still, the Mississippi tooth is, literally, one of only a handful of North American ceratopsian fossils from a marine context. Compared to other types of dinosaurs, hadrosaur bones and teeth are the most common dinosaur fossils from Campanian and Maastrichtian marine sediments (Schwimmer, 1997). A possible explanation for the scarcity of ceratopsian remains versus that of other dinosaur taxa recovered from marine deposits may lie in habitat preferences. A summary of generalized ceratopsian lithofacies associations suggests an affinity for "lacustrine, alluvial, and coastal plain" habitats, at least among Ceratopsidae (Eberth, 2010). Alluvial wetland ecosystems can be separated into riparian (channel margin) and more distal floodplain habitats - clast size decreasing with increasing distance from the channel. A study of alluvial wetland lithofacies in the upper Maastrichtian Hell Creek Formation documents a greater proportional contribution of Triceratops remains (out of seven dinosaur families) to floodplain (muddy) over fluviatile (sandy) deposits. The hadrosaur Edmontosaurus is found with greater frequency in the latter (Lyson \& Longrich, 2011). If rivers are the principal conveyor of bloat-and-float dinosaur carcasses to the marine realm, then a possible preference among coastal plain ceratopsids for habitats outside of riparian zones may explain their paucity in marine sediments.

The tooth described here exhibits mechanical abrasion (see Description) ostensibly due to fluviatile transport since its exhumation. Thus, a relatively uneroded condition is presumed for the specimen prior to burial. Not knowing the exact stratigraphic origin of the specimen, or whether it fell loose from an as yet undiscovered partial dentary or was buried in isolation, precludes any further speculation as to its postmortem journey and exactly when it entered the Owl Creek depositional system. Nonetheless, based on the locality's close proximity to the eastern side of the Mississippi Embayment at the time as well as its near-shore sedimentological context (Figs. 1, 4), we consider it most parsimonious that the tooth originated from an animal in that region, rather than a carcass that had floated from the direction of Laramidia.

\section{Age}

The Owl Creek Formation lies entirely within the upper Maastrichtian (Fig. 2), according to published ammonite stratigraphy (Larina et al., 2016) and non-cephalopod mollusk assemblage zonation (Sohl \& Koch, 1986). Planktonic foraminiferan zonation is consistent with the deposits being at least partly (or mostly) within the upper Maastrichtian (e.g., Puckett, 2005), although these are likely less reliable than ammonites or dinoflagellates for identifying that lithostratigraphic interval (Larina et al., 2016). Owl Creek dinocyst composition immediately below the K-Pg boundary on the opposite side of the Mississippi Embayment in Missouri supports a latest Maastrichtian age for the uppermost part of the formation (Oboh-Ikuenobe et al., 2012). Finally, at the head of the embayment in southern Illinois, ${ }^{40} \mathrm{~K} /{ }^{40} \mathrm{Ar}$ dating of pelletal glauconite in the uppermost Owl Creek Formation yielded a an age of $65.7 \pm 1.4 \mathrm{Ma}$ (Reed et al., 1977). As indicated above, the exact placement of the tooth within the Owl Creek is uncertain, but associated fossils suggest that it is from considerably closer to the K-Pg boundary (top) than it is to the base of the unit. According to Matt Garb of Brooklyn College (pers. comm., 2016), scaphitid ammonite steinkerns in the fossil float accompanying the ceratopsian tooth are almost 
185 entirely dominated by Discoscaphites iris (Conrad, 1858; Fig. 3C,E), which equates to the

186 uppermost portion of calcareous nannofossil zone CC 26 of Perch-Nielsen (1985) within the

187 latest Maastrichtian (Fig. 2). Thus, we posit that the ceratopsian tooth described here dates to the

188 late Maastrichtian.

189 Reworking is always a consideration with condensed, phosphatic pebble beds. To date, 190 suspected anachronistic fossils have not been detected at any interval within the Owl Creek

191 Formation. Considering the exceptional condition of the tooth, and that it was collected from

192 modern stream lag below a small waterfall produced by a resistant calcareous sandstone ledge

193 (Ripley Formation, Chiwapa Member), prior to which it had traveled at least several meters

194 across the irregular surface of the exposed sandstone, reworking from a notably older Cretaceous

195

196

197

198

199

200

201

202

203

204

205

206

207

208

209

210

211

212

213

214

215

216

217

218

219

220

221

222

223

224

225

226

227

228

229

230 interval prior to entombment in the Owl Creek sediments is highly unlikely.

\section{METHODS}

In order to illustrate the details of MMNS VP-7969 at high resolution, stacked images were produced with a Visionary Digital Passport system (Dun, Inc., Virginia, USA). The stacking device was interfaced with a Canon EOS 6D camera (Canon, Inc., Tokyo, Japan) with attached $50 \mathrm{~mm}$ macro lens and a 1.4× Tamron extension, at a magnification setting of 1:2. Images were processed within Helicon Focus 5.3 (Helicon Soft Ltd., Kharkiv, Ukraine).

To produce a three-dimensional digital model for archival and illustration purposes, MMNS VP-7969 was digitized using a NextEngine 3D Scanner Ultra 3D with MultiDrive (NextEngine, Inc., Santa Monica, California, USA). The initial scans were acquired and processed in ScanStudio PRO 2.0.2 (ShapeTools LLC and NextEngine, Inc., Santa Monica, California, USA). Data were collected in several passes, with all set for the maximum resolution on the scanner (6,300 points per square millimeter), using macro mode, and assuming a dark target object. The first pass included six scans taken around the long (apico-basal) axis of the tooth. The second pass included three scans bracketing the apical view of the tooth, and the third pass included three scans bracketing the basal view of the tooth. A final scan captured a portion of the tooth in distal view. The scans were aligned using both manual and automatic alignment, and then fused into a single watertight mesh using the "mesh reconstruction" fuse method (high resolution mesh fitting, and relax fitting selected as an option). This mesh was downsampled to reduce file size, creating a final mesh of 83,312 vertices and 166,620 faces. The file was exported in stereolithography (STL) format and is archived at MorphoSource (http://www.morphosource.org/Detail/SpecimenDetail/Show/specimen_id/4475).

Measurements were taken from the original specimen using digital calipers, to the nearest $0.1 \mathrm{~mm}$. Comparison with measurements taken from the digital model showed the latter to be consistent with the physical specimen to between $0.5-2.5 \%$.

All fossils figured and described here are accessioned at the Mississippi Museum of Natural Science (MMNS). The tooth was molded in silicone rubber, and a limited number of plastic resin casts are available to research institutions by placing requests with the MMNS.

\section{Institutional abbreviations}

AZMNH, Arizona Museum of Natural History, Mesa, Arizona, USA; MMNS, Mississippi Museum of Natural Science, Mississippi Department of Wildlife, Fisheries and Parks, Jackson, Mississippi, USA.

\section{SYSTEMATIC PALEONTOLOGY}


231

232

233

234

235

236

237

238

239

240

241

242

243

244

245

246

247

248

249

250

251

252

253

254

255

256

257

258

259

260

261

262

263

264

265

266

267

268

269

270

271

272

273

274

275

276

Dinosauria Owen, 1842

Ornithischia Seeley, 1887

Ceratopsia Marsh, 1890

Ceratopsoidea Hay, 1902

Ceratopsidae Marsh, 1888

Ceratopsidae indet.

Referred material. MMNS VP-7969, an isolated right dentary tooth, Fig. 5.

Locality and horizon. MMNS locality MS.73.001b, Union County, Mississippi, United States of America (Fig. 1); Owl Creek Formation (late Maastrichtian). Precise locality data are on file at MMNS and are available to qualified investigators upon request.

Description. For simplicity, the following description presumes that the tooth is from the right dentary. This is based on the sharply protruding primary ridge, characteristic of dentary teeth in ceratopsids and contrasting with the relatively subdued primary ridge in maxillary teeth. Once oriented as a dentary tooth, the offset of the primary ridge must be in the mesial direction, and the tooth is thus from the right side (Mallon \& Anderson, 2014). Terminology follows that illustrated by Tanoue et al. (2009:fig. 2).

MMNS VP-7969 preserves both the crown and the root of the tooth (Fig. 5). Portions of the crown were slightly chipped and the extreme ends of the roots were broken off prior to discovery. Due to dark and consistent coloration across the surface of the tooth, it is not possible to describe enamel distribution with any confidence.

The crown as preserved is taller $(18.9 \mathrm{~mm})$ than wide $(15.8 \mathrm{~mm})$ in lingual view (Fig. 5C,D). A slight peak at the mesial and distal edges, where the root intersects with the carinae, produces a rhomboid profile. A prominent primary ridge divides the tooth crown into a smaller mesial lobe and a larger distal lobe (Fig. 5G). Towards the base of the crown, the ridge has a slight mesial curvature (Fig. 5C,D). In mesial and distal views, the primary ridge is strongly arched, and a slight inflection marks the point where the ridge and the cingulum/root connect (Fig. 5A,B,E,F). The primary ridge is fin-like and strongly compressed mesio-distally. The lingual edge of the ridge bears very fine and imbricating crenulations. A single, very poorly defined secondary ridge occurs at the mesial edge of the mesial lobe (Fig. 5C); otherwise, secondary ridges are completely absent. No unambiguous denticles appear on the tooth, either. A distinct cingulum separates the crown from the root on the tooth's lingual surface (Fig. 5E,G). As preserved, the maximum apico-basal length of the entire tooth in lingual view is $26.8 \mathrm{~mm}$.

In labial view, the crown and root are not distinctly separated (Fig. 5I,J). The labial surface is gently arched from mesio-distally, with at least seven faint plications along the surface of the tooth oriented apico-basally. A flat, approximately quadrangular wear surface marks the apical end of the tooth in this view. A handful of minor scratches mark this area, although the lack of consistent orientation suggests that they are taphonomic in origin rather than representing microwear. Assuming a standard tooth orientation for a ceratopsid, the wear facet was at least subvertical. As preserved, the maximum apico-basal length of the entire tooth in labial view is 28.4 and the maximum width is $16.8 \mathrm{~mm}$.

The root is bipartite, with the two halves having a maximum span of $22.2 \mathrm{~mm}$. The labial root is more robust and longer than the lingual root (Fig. 5E). A v-shaped resorption groove marks the basal surface of the root (Fig. 5K,L).

\section{DISCUSSION}


280

281

282

283

284

285

286

287

288

289

290

291

292

293

294

295

296

297

298

299

300

301

302

303

304

305

306

307

308

309

310

311

312

313

314

315

316

317

318

319

320

321

322

Referral to Ceratopsidae. The prominent primary ridge and split root of MMNS VP7969 definitively distinguish it from teeth belonging to other ornithischian dinosaurs present in North America during the Late Cretaceous, such as hadrosaurs, ankylosaurs, pachycephalosaurs, and basal ornithopods, all of which lack these features. This gross morphology, thus, is most consistent with referral to Ceratopsidae. However, to avoid the hazards of "overidentification," we here examine the phylogenetic distribution of notable apomorphies in MMNS VP-7969 to arrive at the most conservative identification possible. This is particularly important in light of teeth described for Turanoceratops, a non-ceratopsid ceratopsoid from Uzbekistan that also displays some apomorphies historically recognized only in ceratopsids (Sues \& Averianov, 2009; Farke et al., 2009). The subject is further complicated by variation across the tooth row in ceratopsids; teeth at the very mesial or distal end differ from those in the middle in the development of some features (Hatcher, Marsh \& Lull, 1907).

Split tooth root. This feature is noted in Turanoceratops tardabilis (Nessov, Kaznyshkina \& Cherepanov, 1989; Sues \& Averianov, 2009) and all ceratopsids for which the relevant tooth anatomy is preserved, but does not occur in other ceratopsians, nor in other ornithischians as a whole.

Absence of secondary ridges on tooth crown. Secondary ridges paralleling the median carina (primary ridge) are common in teeth of non-ceratopsid neoceratopsians (Tanoue, You \& Dodson, 2009), and also occur variably in Turanoceratops (Sues \& Averianov, 2009) as well as in Zuniceratops christopheri (personal observation, A. Farke; AZMNH P2224, AZMNH P3600) . Due to their variable occurrence in T. tardabilis, the near absence of these ridges in MMNS VP7969 can only restrict a tooth to Ceratopsoidea.

Projecting, blade-like primary ridge on dentary teeth. The primary ridge projects strongly from the body of the tooth in MMNS VP-7969 and all ceratopsids, but is far more subdued in dentary teeth of T. tardabilis (Sues \& Averianov, 2009:fig. 2e,f) and Z. christopheri (personal observation, A. Farke; AZMNH P3600). Most notably, in the known Turanoceratops specimens (as well as non-ceratopsoid neoceratopsians such as Protoceratops), the carina is smoothly continuous with the root in mesial and distal views. By contrast, the carina is arched away from the main body of the tooth in MMNS VP-7969 and many ceratopsid dentary teeth (but not all, particularly from those at the extreme ends of the rows). Our observations suggest that the morphology is only found in Ceratopsidae.

In total, the anatomy of MMNS VP-7969 identifies it as a tooth from a ceratopsid dinosaur. At present, a more constrained identification is not possible due to the general similarities in teeth across ceratopsid clades (Mallon \& Anderson, 2014). However, only chasmosaurines are known in North America during the late Maastrichtian, so the silhouettes in Fig. 4 are illustrated as such.

Biogeographic and paleogeographic implications. The tooth described here (MMNS VP-7969) represents the first reported occurrence of Ceratopsidae from eastern North America (Appalachia). Previous reports of ceratopsians from Appalachia have been from non-ceratopsid neoceratopsians, including isolated teeth from the Aptian-aged Arundel Formation of Maryland and a potential leptoceratopsid from the Campanian-aged Tar Heel Formation of North Carolina (Chinnery et al., 1998; Chinnery-Allgeier \& Kirkland, 2010; Longrich, 2016). The dispersal route of these earlier ceratopsians into Appalachia is uncertain, and the overall evidence supports a lengthy geographic separation of Appalachia from Laramidia during the Late Cretaceous (late Cenomanian to latest Maastrichtian, 95-66 Ma, Slattery et al., 2015). Although there is some limited biogeographical evidence for occasional connections between Europe and Appalachia 
323 during the Late Cretaceous (summarized in Csiki-Sava et al., 2015), no ceratopsids are known

324 from Europe. So, a European origin for the animal associated with the Mississippi tooth is highly

325 unlikely.

326

327

328

329

330

331

332

333

334

335

336

337

338

339

340

341

342

343

344

345

346

347

348

349

350

351

352

353

354

355

356

357

358

359

360

361

362

363

364

365

366

367

368

We thus hypothesize that the occurrence of a ceratopsid in Mississippi represents a dispersal event from western North America into eastern North America. Significantly, this is the first time that a representative of this previously Laramidian dinosaur clade has been identified from eastern North America. This provides strong biogeographic evidence for a physical connection between eastern and western North America during the late Maastrichtian (Fig. 4).

Because many regions of the former Western Interior Seaway do not have the relevant strata preserved or accessible, the seaway's extent during the terminal Maastrichtian has been debated (summarized in Berry, in press; Boyd \& Lillegraven, 2011; Slattery et al., 2015 and references therein). For instance, ammonite distribution suggests a marine connection from the Gulf of Mexico northward to South Dakota (but not continuous with marine environments around present-day Greenland) up until the Hoploscaphites nebrascensis biozone during part of the late Maastrichtian (Kennedy et al., 1998). In turn, the shared occurrence of the plant "Cissites" panduratus between Laramidia and Appalachia during the late Maastrichtian supports a subaerial connection between the two land masses during this time, too (Berry, in press). The ceratopsid tooth in Mississippi provides additional evidence consistent with this scenario.

Eastern dinosaurs. Non-avian dinosaurs from Cretaceous deposits in the eastern U. S. have been well publicized (e.g., Weishampel \& Young, 1996; Schwimmer, 1997)(e.g., Weishampel \& Young, 1996; Schwimmer, 1997). Although few discoveries are complete enough for comprehensive description and precise taxonomic assignment, recent notable exceptions include a tyrannosauroid and hadrosaurid from Alabama (Carr, Williamson \& Schwimmer, 2005; Prieto-Márquez, Erickson \& Ebersole, 2016a,b). Cretaceous dinosaur finds from eastern North America are not rare, but they are infrequent. Since Cretaceous dinosaur remains were first reported on the east coast in the $1850 \mathrm{~s}$, numerous specimens representing several groups, both ornithischian and theropod, have been reported from Mississippi to New Jersey. Most of this material consists of isolated and often fragmentary elements, like the ceratopsian tooth reported herein. Collectively, however, the scattered discoveries across the Gulf and Atlantic Coastal Plain reveal an eastern North American Cretaceous dinosaur bestiary that included six major dinosaur clades. To date, these include hadrosauroids (e.g., Langston, Jr., 1960; Prieto-Márquez, Weishampel \& Horner, 2006; Prieto-Márquez, Erickson \& Ebersole, 2016a), ankylosaurians (Langston, Jr., 1960; Weishampel \& Young, 1996; Stanford, Weishampel \& Deleon, 2011), tyrannosauroids (Baird \& Horner, 1979; Schwimmer et al., 1993; Carpenter et al., 1997; Carr, Williamson \& Schwimmer, 2005), dromaeosaurids (Kiernan \& Schwimmer, 2004), ornithomimids (Baird \& Horner, 1979; Carpenter, 1982; Schwimmer et al., 1993), and ceratopsians (Chinnery et al., 1998; Longrich, 2016; this paper).

Mississippi's published fragmentary dinosaur remains currently encompass only hadrosaurs (e.g., Horner, 1979) and indeterminate theropods (Carpenter, 1982), although one association of over two dozen elements of a single juvenile hadrosaur has been described (Kaye $\&$ Russell, 1973). One of the unassigned theropod pedal phalanges (Carpenter, 1982) was later identified as Mississippi's first known ornithomimid (Baird, 1986). In addition to previously described Mississippi material (Carpenter, 1982), MMNS possesses unpublished, largely isolated elements of hadrosaurs (the most commonly encountered), nodosaurs (teeth and fragmentary bones), dromaeosaurids (teeth), and ornithomimids (the second most common dinosaur). Except for the ceratopsian tooth, all MMNS Mississippi dinosaur holdings (most of it unpublished) are 
369 derived from upper Santonian through lower Maastrichtian deposits. Dinosaurs have been

370 reported (Ebersole \& King, 2011) but are otherwise undescribed from the upper Maastrichtian of

371 the Gulf Coastal Plain. Many more dinosaur discoveries have been encountered and

372 substantiated in the Maastrichtian of the Atlantic Coastal Plain, namely from the Navesink

373 Formation in New Jersey (see reviews by Weishampel \& Young, 1996; Gallagher, 1997).

374

375

376

377

378

379

380

381

382

383

384

385

386

387

388

389

390

391

392

393

394

395

396

397

\section{CONCLUSIONS}

The ceratopsid tooth from the Owl Creek Formation of Mississippi represents the first unequivocal occurrence of this clade in Appalachia (eastern North America). The fossil is consistent with the hypothesis that clades from Laramidia (western North America) dispersed eastward during the retreat of the Western Interior Seaway sometime during the Maastrichtian. We predict that future work will uncover additional evidence of "western" vertebrate clades in Appalachia; in particular, careful placement within a geological context will help to establish the exact timing and tempo of the seaway retreat.

\section{ACKNOWLEDGEMENTS}

We extend our gratitude to T. L. Harrell, Jr., who first recognized the tooth as belonging to a ceratopsian and introduced the writers to one another, which led to the current project. Harrell also identified the mosasaur teeth found at the ceratopsian locality (Fig. $3 \mathrm{H}$ ). Thanks also to P. Kuchirka, MMNS volunteer, who molded/cast the tooth; D. Kitchens, who graciously allowed us access to his property where the tooth was found; M. Garb of Brooklyn College (CUNY), who identified ammonites from the tooth locality, which were useful for biostratigraphic determinations; J. Ebersole of McWane Science Center for assistance with vertebrate fossil identifications; K. Berry for discussion on Cretaceous biogeography; and Colorado Plateau Geosystems for licensed use of the paleogeographic maps. Discussions with F. Varriale were helpful in establishing the orientation of the specimen. Comments from A. Averianov, P. Dodson, D. Fowler, B. McFeeters, H.-D. Sues, and an anonymous reviewer were helpful in revising the manuscript.

398 
399

400

401

402

403

404

405

406

407

408

409

410

411

412

413

414

415

416

417

418

419

420

421

422

423

424

425

426

427

428

429

430

431

432

433

434

435

436

437

438

439

440

441

442

443

444

\section{REFERENCES}

Agassiz L. 1843. Recherches Sur Les Poissons Fossiles. Tome III (livr. 15-16). Neuchatel: Imprimérie de Petitpierre.

Arambourg C. 1935. Note préliminaire sur les vertébrés fossiles des Phosphates du Maroc. Bulletin de la Société Géologique de France 5:413-439.

Baird D. 1986. Upper Cretaceous reptiles from the Severn Formation of Maryland. The Mosasaur 3:63-85.

Baird D., Horner JR. 1979. Cretaceous dinosaurs of North Carolina. Brimleyana 2:1-28.

Berry K. in press. New paleontological constraints on the paleogeography of the Western Interior Seaway near the end of the Cretaceous (Campanian - Maastrichtian) with a special emphasis on the paleogeography of southern Colorado. Rocky Mountain Geology 52.

Bicker AR Jr. 1969. Geologic map of Mississippi, scale 1:500,000. Mississippi Mineral Resources Institute, University of Mississippi.

Bishop GA. 1986. Two new crabs, Parapaguristes tuberculatus and Palaeoxantho libertiensis, from the Prairie Bluff Formation (Middle Maastrichtian), Union County, Mississippi, U.S.A. Proceedings of the Biological Society of Washington 99:604-611.

Boyd DW., Lillegraven JA. 2011. Persistence of the Western Interior Seaway: Historical background and significance of ichnogenus Rhizocorallium in Paleocene strata, southcentral Wyoming. Rocky Mountain Geology 46:43-69. DOI: 10.2113/gsrocky.46.1.43.

Carpenter K. 1982. The oldest Late Cretaceous dinosaurs in North America? Mississippi Geology 3:11-17.

Carpenter K., Russell D., Baird D., Denton R. 1997. Redescription of the holotype of Dryptosaurus aquilunguis (Dinosauria: Theropoda) from the Upper Cretaceous of New Jersey. Journal of Vertebrate Paleontology 17:561-573. DOI: 10.1080/02724634.1997.10011003.

Carr TD., Williamson TE., Schwimmer DR. 2005. A new genus and species of tyrannosauroid from the Late Cretaceous (Middle Campanian) Demopolis Formation of Alabama. Journal of Vertebrate Paleontology 25:119-143.

Chinnery BJ., Lipka TR., Kirkland JI., Parrish JM., Brett-Surman M. 1998. Neoceratopsian teeth from the Lower to middle Cretaceous of North America. New Mexico Museum of Natural History and Science Bulletin 14:297-302.

Chinnery-Allgeier BJ., Kirkland JI. 2010. An update on the paleobiogeography of ceratopsian dinosaurs. In: Ryan MJ, Chinnery-Allgeier BJ, Eberth DA eds. New Perspectives on Horned Dinosaurs: The Royal Tyrrell Museum Ceratopsian Symposium. Bloomington, Indiana: Indiana University Press, 387-404.

Cobban WA. 1974. Some ammonoids from the Ripley Formation of Mississippi, Alabama, and Georgia. United States Geological Survey Journal of Research 2:81-88.

Cobban WA., Kennedy WJ. 1991a. Some Upper Cretaceous ammonites from the Nacatoch Sand of Hempstead County, Arkansas. United States Geological Survey Bulletin 1985C:1-5.

Cobban WA., Kennedy WJ. 1991b. Upper Cretaceous (Maastrichtian) ammonites from the Nostoceras alternatum zone in southwestern Arkansas. United States Geological Survey Bulletin 1985E:1-6.

Cobban WA., Kennedy WJ. 1995. Maastrichtian ammonites chiefly from the Prairie Bluff Chalk in Alabama and Mississippi. Paleontological Society Memoir 44:1-40.

Conrad TA. 1830. On the geology and organic remains of a part of the peninsula of Maryland. Containing descriptions of twenty-nine species of fossil shells, noticed in the preceding 
paper. Journal of the Academy of Natural Sciences of Philadelphia, First Series 6:205231.

Conrad TA. 1853. Descriptions of new fossil shells of the United States. Journal of the Academy of Natural Sciences of Philadelphia, Second Series 2:273-276.

Conrad TA. 1858. Observations on a group of Cretaceous fossil shells, found in Tippah County, Miss., with descriptions of fifty-six new species. Journal of the Academy of Natural Sciences of Philadelphia, Second Series 3:323-336.

Conrad TA. 1860. Descriptions of new Cretaceous and Eocene fossils of Mississippi and Alabama. Journal of the Academy of Natural Sciences of Philadelphia, Second Series 4:275-298.

Csiki-Sava Z., Buffetaut E., Ösi A., Pereda-Suberbiola X., Brusatte SL. 2015. Island life in the Cretaceous - faunal composition, biogeography, evolution, and extinction of land-living vertebrates on the Late Cretaceous European archipelago. ZooKeys 469:1-161. DOI: 10.3897/zookeys.469.8439.

Ebersole SM., King JL. 2011. A review of the non-avian dinosaurs from the Late Cretaceous of Alabama, Mississippi, Georgia, and Tennessee. Alabama Museum of Natural History Bulletin 28:81-93.

Eberth DA. 2010. A review of ceratopsian paleoenvironmental associations and taphonomy. In: Ryan M, Chinnery-Allgeier B, Eberth D eds. New Perspectives on Horned Dinosaurs: The Royal Tyrrell Museum Ceratopsian Symposium. Bloomington: Indiana University Press, 428-446.

Eifert T. 2009. The Cretaceous-Paleogene transition in the northern Mississippi Embayment, S.E. Missouri: palynology, micropaleontology, and evidence of a mega-tsunami deposit. Ph.D. dissertation Thesis. Rollo, Missouri: Missouri University of Science and Technology.

Farke AA., Sampson SD., Forster CA., Loewen MA. 2009. Turanoceratops tardabilis-sister taxon, but not a ceratopsid. Naturwissenschaften 96:869-870. DOI: 10.1007/s00114-0090543-8.

Feldmann RM., Portell RW. 2007. First report of Costacopluma (Decapoda: Brachyura: Retroplumidae) from the Eocene of Alabama, U.S.A. Journal of Crustacean Biology 27:90-96. DOI: 10.1651/S-2712.1.

Gabb WM. 1860. Descriptions of new species of American Tertiary and Cretaceous fossils. Journal of the Academy of Natural Sciences of Philadelphia 4:375-406.

Gallagher W. 1997. When Dinosaurs Roamed New Jersey. New Brunswick, N.J: Rutgers University Press.

Hatcher JB., Marsh OC., Lull RS. 1907. The Ceratopsia. United States Geological Survey Monograph 49:1-300.

Hay OP. 1902. Bibliography and catalogue of the fossil Vertebrata of North America. Bulletin of the United States Geological Survey 179:1-868.

Horner JR. 1979. Upper Cretaceous dinosaurs from the Bearpaw Shale (marine) of South-central Montana with a checklist of Upper Cretaceous dinosaur remains from marine sediments in North America. Journal of Paleontology 53:566-577.

Kaye JM., Russell DA. 1973. The oldest record of hadrosaurian dinosaurs in North America. Journal of Paleontology 47:91-93.

Kennedy WJ., Cobban WA. 1993. Ammonites from the Saratoga Chalk (Upper Cretaceous), Arkansas. Journal of Paleontology 67:404-434. 
491 Kennedy WJ., Landman NH., Christensen WK., Cobban WA., Hancock JM. 1998. Marine

492

493

494

495

496

497

498

499

500

501

502

503

504

505

506

507

508

509

510

511

512

513

514

515

516

517

518

519

520

521

522

523

524

525

526

527

528

529

530

531

532

533

534

535

536 connections in North America during the late Maastrichtian: palaeogeographic and palaeobiogeographic significance of Jeletzkytes nebrascensis Zone cephalopod fauna from the Elk Butte Member of the Pierre Shale, SE South Dakota and NE Nebraska. Cretaceous Research 19:745-775. DOI: 10.1006/cres.1998.0129.

Kiernan CR., Schwimmer DR. 2004. First record of a velociraptorine theropod (Tetanurae, Dromaeosauridae) from the eastern Gulf coastal United States. The Mosasaur 7:89-93.

Lamarck JBPA. 1806. Suite des Mémoires sur les fossiles des environs de Paris. Genre LXXIV. Annales du Muséum national d'histoire naturelle 8:156-166.

Landman NH., Johnson RO., Edwards LE. 2004. Cephalopods from the Cretaceous/Tertiary boundary interval on the Atlantic Coastal Plain, with a description of the highest ammonite zones in North America. Part 1, Maryland and North Carolina. American Museum Novitates 3454:1-64.

Langston, Jr. W. 1960. The vertebrate fauna of the Selma Formation of Alabama. Part VI. The dinosaurs. Fieldiana, Geology 3:315-361.

Larina E., Garb M., Landman N., Dastas N., Thibault N., Edwards L., Phillips G., Rovelli R., Myers C., Naujokaityte J. 2016. Upper Maastrichtian ammonite biostratigraphy of the Gulf Coastal Plain (Mississippi Embayment, southern USA). Cretaceous Research 60:128-151. DOI: 10.1016/j.cretres.2015.11.010.

Lehman TM. 1996. A horned dinosaur from the El Picacho Formation of West Texas, and review of ceratopsian dinosaurs from the American Southwest. Journal of Paleontology 70:494-508.

Lehman TM., Wick SL., Barnes KR. 2016. New specimens of horned dinosaurs from the Aguja Formation of West Texas, and a revision of Agujaceratops. Journal of Systematic Palaeontology 0:1-34. DOI: 10.1080/14772019.2016.1210683.

Leidy J. 1856. Notice of remains of extinct turtles of New Jersey, collected by Prof. Cook, of the State Geological Survey, under the direction of Dr. W. Kitchell. Proceedings of the Academy of Natural Sciences of Philadelphia 8:301-327.

Loewen MA., Sampson SD., Lund EK., Farke AA., Aguillón Martínez MC., de Leon CA., Rodríguez de la Rosa RA., Getty MA., Eberth DA. 2010. Horned dinosaurs (Ornithischia: Ceratopsidae) from the Upper Cretaceous (Campanian) Cerro del Pueblo Formation, Coahuila, Mexico. In: Ryan MJ, Chinnery-Allgeier BJ, Eberth DA eds. New Perspectives on Horned Dinosaurs: The Royal Tyrrell Museum Ceratopsian Symposium. Bloomington: Indiana University Press, 99-116.

Longrich NR. 2016. A ceratopsian dinosaur from the Late Cretaceous of eastern North America, and implications for dinosaur biogeography. Cretaceous Research 57:199-207. DOI: 10.1016/j.cretres.2015.08.004.

Lyson TR., Longrich NR. 2011. Spatial niche partitioning in dinosaurs from the latest Cretaceous (Maastrichtian) of North America. Proceedings of the Royal Society of London B: Biological Sciences 278:1158-1164. DOI: 10.1098/rspb.2010.1444.

Mallon JC., Anderson JS. 2014. The functional and palaeoecological implications of tooth morphology and wear for the megaherbivorous dinosaurs from the Dinosaur Park Formation (Upper Campanian) of Alberta, Canada. PLOS ONE 9:e98605. DOI: 10.1371/journal.pone.0098605.

Mancini EA., Puckett TM., Tew BH., Smith CC. 1995. Upper Cretaceous sequence stratigraphy of the Mississippi-Alabama area. Gulf Coast Association of Geological Societies 
537

538

539

540

541

542

543

544

545

546

547

548

549

550

551

552

553

554

555

556

557

558

559

560

561

562

563

564

565

566

567

568

569

570

571

572

573

574

575

576

577

578

579

580

581

582

Transactions 45:377-384.

Mantell GA. 1829. A tabular arrangement of the organic remains of the county of Sussex. Transactions of the Geological Society of London 2:201-216.

Marsh OC. 1888. A new family of horned dinosaurs from the Cretaceous. American Journal of Science 36:477-478.

Marsh OC. 1890. Additional characters of the Ceratopsidae, with notice of new Cretaceous dinosaurs. American Journal of Science s3-39:418-426. DOI: 10.2475/ajs.s3-39.233.418.

Martínez-Díaz JL., Phillips GE., Nyborg T., Espinosa B., Távora V de A., Centeno-García E., Vega FJ. 2016. Lilliput effect in a retroplumid crab (Crustacea: Decapoda) across the K/Pg boundary. Journal of South American Earth Sciences 69:11-24. DOI: 10.1016/j.jsames.2016.03.007.

Morton SG. 1834. Synopsis of the organic remains of the Cretaceous group of the United States. Illustrated by nineteen plates, to which is added an appendix containing a tabular view of the Tertiary fossils discovered in America. Philadelphia: Key and Biddle.

Nessov LA., Kaznyshkina LF., Cherepanov GO. 1989. Ceratopsian dinosaurs and crocodiles of the Mesozoic of middle Asia. In: Bogdanova TN, Khozatsky LI eds. Theoretical and Applied Aspects of Modern Paleontology. Leningrad: Nauka, 144-154.

Oboh-Ikuenobe FE., Spencer MK., Campbell CE., Haselwander RD. 2012. A portrait of Late Maastrichtian and Paleocene palynoflora and paleoenvironment in the northern Mississippi Embayment, southeastern Missouri. Palynology 36:63-79. DOI: 10.1080/01916122.2012.679208.

Owen R. 1842. Report on British fossil reptiles. Part II. Report of the Eleventh Meeting of the British Association for the Advancement of Science 1841:66-204.

Perch-Nielsen K. 1985. Mesozoic calcareous nannofossils. In: Bolli HM, Saunders JB, PerchNielsen K eds. Plankton stratigraphy, Volume 1: Planktic foraminifera, calcareous nannofossils and calpionellids. New York: Cambridge University Press, 329-426.

Phillips GE. 2010. A distinctive lithofacies between the Prairie Bluff and Owl Creek formations (Upper Cretaceous) of north Mississippi and its characteristic faunal content. Journal of the Mississippi Academy of Sciences 55:78.

Phillips GE., Nyborg T., Vega FJ. 2014. Icriocarcinidae: A family of portunoid crabs from the Upper Cretaceous of North America. Paläontologische Zeitschrift 88:139-158. DOI: 10.1007/s12542-013-0190-4.

Porras-Múzquiz HG., Lehman TM. 2011. A ceratopsian horncore from the Olmos Formation (early Maastrichtian) near Múzquiz, Mexico. Revista Mexicana de Ciencias Geológicas 28:262-266.

Prieto-Márquez A., Erickson GM., Ebersole JA. 2016a. A primitive hadrosaurid from southeastern North America and the origin and early evolution of "duck-billed" dinosaurs. Journal of Vertebrate Paleontology 36:e1054495. DOI: 10.1080/02724634.2015.1054495.

Prieto-Márquez A., Erickson GM., Ebersole JA. 2016b. Anatomy and osteohistology of the basal hadrosaurid dinosaur Eotrachodon from the uppermost Santonian (Cretaceous) of southern Appalachia. PeerJ 4:e1872. DOI: 10.7717/peerj.1872.

Prieto-Márquez A., Weishampel DB., Horner JR. 2006. The dinosaur Hadrosaurus foulkii, from the Campanian of the East Coast of North America, with a reevaluation of the genus. Acta Palaeontologica Polonica 51:77-98.

Pryor WA. 1960. Cretaceous sedimentation in Upper Mississippi Embayment. AAPG Bulletin 
583

584

585

586

587

588

589

590

591

592

593

594

595

596

597

598

599

600

601

602

603

604

605

606

607

608

609

610

611

612

613

614

615

616

617

618

619

620

621

622

623

624

625

626

627

628

44:1473-1504.

Puckett TM. 2005. Santonian-Maastrichtian planktonic foraminiferal and ostracode biostratigraphy of the northern Gulf Coastal Plain, USA. Stratigraphy 2:117-146.

Rathbun MJ. 1926. Crustacea. In: Wade B ed. The fauna of the Ripley Formation of Coon Creek, Tennessee, United States Geological Survey Professional Paper 137. 184-191.

Reed PC., Masters JM., Hester NC., Glass HD. 1977. Lithology and geochronology of Cretaceous and Tertiary marine deposits in Illinois. Geological Society of America Abstracts with Programs 9(5):646.

Rivera-Sylva HE., Hedrick BP., Dodson P. 2016. A centrosaurine (Dinosauria: Ceratopsia) from the Aguja Formation (Late Campanian) of Northern Coahuila, Mexico. PLOS ONE 11:e0150529. DOI: 10.1371/journal.pone.0150529.

Sampson SD., Loewen MA., Farke AA., Roberts EM., Forster CA., Smith JA., Titus AL. 2010. New horned dinosaurs from Utah provide evidence for intracontinental dinosaur endemism. PLOS ONE 5:e12292.

Sampson SD., Lund EK., Loewen MA., Farke AA., Clayton KE. 2013. A remarkable shortsnouted horned dinosaur from the Late Cretaceous (late Campanian) of southern Laramidia. Proceedings of the Royal Society B: Biological Sciences 280:20131186. DOI: 10.1098/rspb.2013.1186.

Say T. 1820. Observations on some species of zoophytes, shells, etc., principally fossil. American Journal of Science, Series 1 2:34-45.

Schäfer W. 1972. Ecology and Palaeoecology of Marine Enviroments [translated from German by I. Oertel]. Chicago: University of Chicago Press.

Schwimmer DR. 1997. Late Cretaceous dinosaurs in eastern USA: A taphonomic and biogeographic model of occurrences. In: Wolberg DL, Rosenberg GD eds. Dinofest International Proceedings Volume. Philadelphia: Academy of Natural Sciences of Philadelphia, 203-211.

Schwimmer DR., Williams GD., Dobie JL., Siesser WG. 1993. Late Cretaceous dinosaurs from the Blufftown Formation in western Georgia and eastern Alabama. Journal of Paleontology 67:288-296. DOI: 10.1017/S0022336000032212.

Seeley HG. 1887. On the classification of the fossil animals commonly named Dinosauria. Proceedings of the Royal Society of London 43:165-171.

Slattery JS., Cobban WA., McKinney KC., Harries PJ., Sandness AL. 2015. Early Cretaceous to Paleocene paleogeography of the Western Interior Seaway: The interaction of eustasy and tectonism. Wyoming Geological Association Guidebook 2015:22-60.

Sohl NF. 1960. Archeogastropoda, Mesogastropoda, and stratigraphy of the Ripley, Owl Creek, and Prairie Bluff Formations. United States Geological Survey Professional Paper 331A:1-151.

Sohl NF. 1964. Neogastropoda, Opisthobranchia, and Basommatophora from the Ripley, Owl Creek, and Prairie Bluff Formations. United States Geological Survey Professional Paper 331B:153-344.

Sohl NF., Koch C. 1983. Upper Cretaceous (Maestrichtian) Mollusca from the Haustator bilira Assemblage Zone in the East Gulf Coastal Plain. United States Geological Survey Open File Report 83-451:1-239.

Sohl NF., Koch C. 1986. Molluscan biostratigraphy and biofacies of the Haustator bilira assemblage zone (Maastrichtian) of the East Gulf Coastal Plain. In: Reinhardt J ed. Stratigraphy and sedimentology of continental, nearshore, and marine Cretaceous 
629

630

631

632

633

634

635

636

637

638

639

640

641

642

643

644

645

646

647

648

649

650

651

652

653

654

655

656

657

658

659

660

661

662

663

664

665

666

667

sediments of the eastern Gulf Coastal Plain. Carrollton, Georgia: Georgia Geological Society, 45-56, 92-99.

Stanford R., Weishampel DB., Deleon VB. 2011. The first hatchling dinosaur reported from the eastern United States: Propanoplosaurus marylandicus (Dinosauria: Ankylosauria) from the Early Cretaceous of Maryland, U.S.A. Journal of Paleontology 85:916-924. DOI: 10.1666/10-113.1.

Stephenson LW. 1941. The larger invertebrate fossils of the Navarro Group of Texas. University of Texas Publication 4101:1-641.

Stephenson LW. 1955. Owl Creek (Upper Cretaceous) fossils from Crowleys Ridge, southeastern Missouri. United States Geological Survey Professional Paper 274E:97140.

Stephenson LW., Monroe WH. 1940. The Upper Cretaceous deposits. Mississippi Geological Survey Bulletin 40:1-296.

Sues H-D., Averianov A. 2009. Turanoceratops tardabilis-the first ceratopsid dinosaur from Asia. Die Naturwissenschaften 96:645-652. DOI: 10.1007/s00114-009-0518-9.

Sullivan RM., Boere AC., Lucas SG. 2005. Redescription of the ceratopsid dinosaur Torosaurus utahensis (Gilmore, 1946) and a revision of the genus. Journal of Paleontology 79:564582.

Sullivan RM., Lucas SG. 2010. A new chasmosaurinae (Ceratopsidae, Dinosauria) from the Upper Cretaceous Ojo Alamo Formation (Naashoibito Member), San Juan Basin, New Mexico. In: Ryan MJ, Chinnery-Allgeier BJ, Eberth DA eds. New Perspectives on Horned Dinosaurs: The Royal Tyrrell Museum Ceratopsian Symposium. Bloomington, Indiana: Indiana University Press, 169-180.

Swann CT., Dew JJ. 2008. Geological map of the Troy, Mississippi 7.5' quadrangle. Mississippi Mineral Resources Institute, University of Mississippi.

Swann CT., Dew JJ. 2009. Geology of the Troy, Miss., 7.5 minute topographic quadrangle, Chickasaw and Pontotoc Counties, Mississippi. Mississippi Mineral Resources Institute Open-File Report 09-2S:1-28.

Tanoue K., You H., Dodson P. 2009. Comparative anatomy of selected basal ceratopsian dentitions. Canadian Journal of Earth Sciences 46:425-439. DOI: 10.1139/E09-030.

Weishampel DB., Barrett PM., Coria RA., Le Loeuff J., Xu X., Zhao X., Sahni A., Gomani EMP., Noto CR. 2004. Dinosaur distribution. In: Dodson P, Weishampel DB, Osmólska H eds. The Dinosauria. Berkeley: University of California Press, 517-606.

Weishampel DB., Young L. 1996. Dinosaurs of the East Coast. Baltimore: Johns Hopkins University Press.

Wick SL., Lehman TM. 2013. A new ceratopsian dinosaur from the Javelina Formation (Maastrichtian) of West Texas and implications for chasmosaurine phylogeny. Naturwissenschaften 100:667-682. DOI: 10.1007/s00114-013-1063-0. 
668 Figure 1. Geologic map of Maastrichtian deposits in northeast Mississippi. The area of interest 669 includes the noteworthy type localities of the Coon Creek Formation (latest Campanian-early 670 Maastrichtian) and Owl Creek Formation (late Maastrichtian). Base map composed by the 671 Mississippi Office of Geology in 2010, from data in Bicker (1969).

672

673

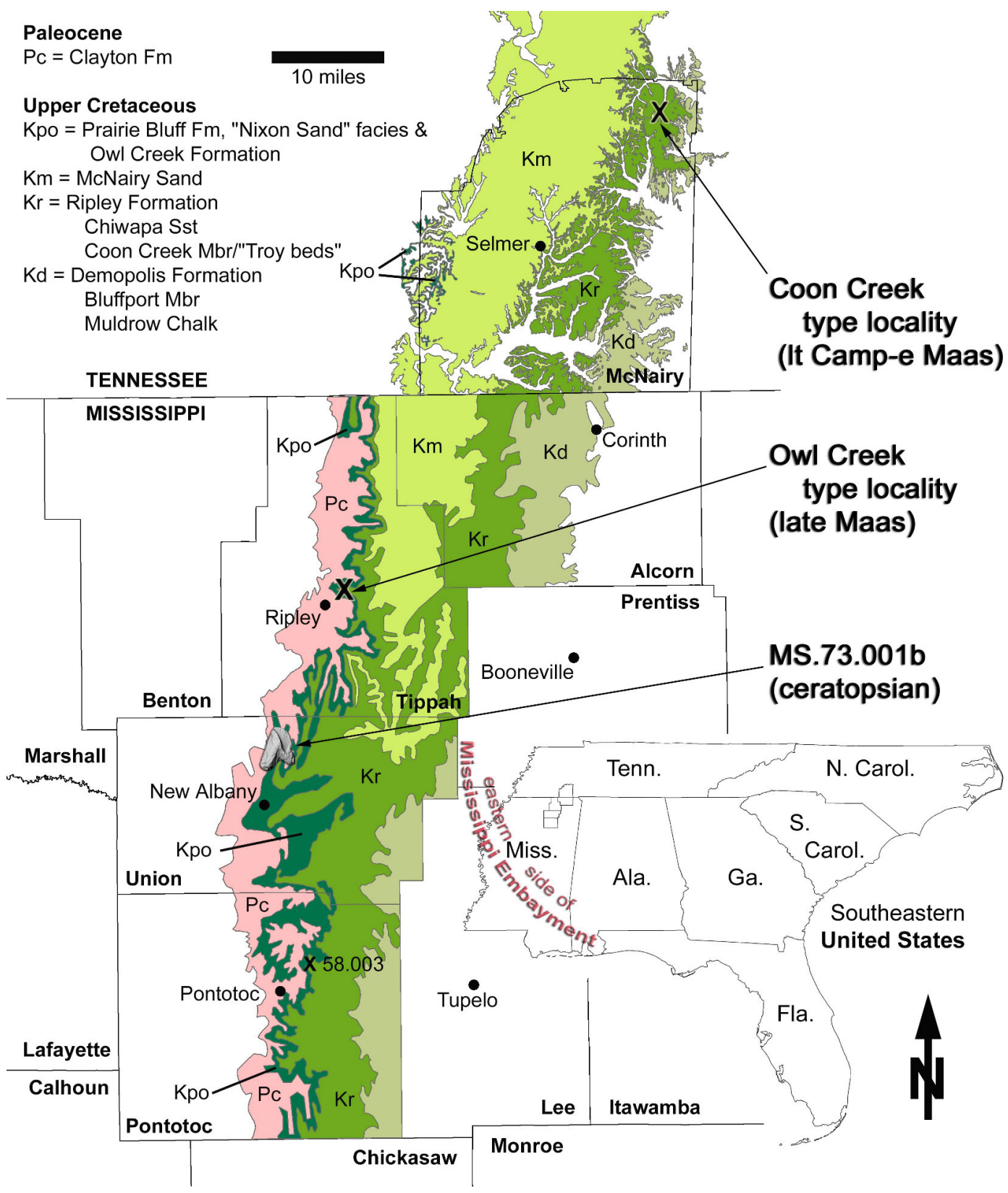


674 Figure 2. Stratigraphic chart of Maastrichtian deposits in northeast Mississippi. Basic chart 675 chronostratigraphy and most of the biostratigraphic columns were produced using TS

676 (TimeScale) Creator (C) 2005-2010, A. Lugowski and J. Ogg). All ages are standardized to the

677 Geologic Time Scale 2016 and the Concise Geologic Time Scale compilation of the International

678 Commission on Stratigraphy and its Subcommission on Stratigraphic Information. The

679 stratigraphic data used in TS Creator is based on numerous events borrowed from many global

680 and regional reference sections and integrated time scales. The Gulf Coastal Plain (GCP)

681 ammonite zones and their correlative ages are based primarily on Cobban (1974), Cobban and

682 Kennedy (1991a,b, 1995; 1993), Landman et al. (2004), and Larina et al. (2016). The

683 relationship of GCP to WIS ammonite zones as presented here should be considered provisional.

684 The position of the stage and substage boundaries is based, in part, on the work of Sohl and Koch

685 (1986). The informal units "Nixon beds," "Troy beds," and "transitional clay" were introduced

686 by Phillips (2010), Swann and Dew (2008, 2009), and Sohl (1960), respectively. The Coon

687 Creek and correlative beds are time transgressive, the Campanian-Maastrichtian boundary being

688 located higher in the section in the northern part of the outcrop belt (Tennessee). A major

689 unconformity is recognized at the base of the Chiwapa Sandstone, separating it from the

690 remainder of the subjacent Ripley Formation. Contrary to the age of the sub-Chiwapa Ripley

691 given here (early Maastrichtian), foraminiferal zonation established for the Gulf Coast by

692 Mancini et al. (1995) and Puckett (2005) defines the Campanian-Maastrichtian boundary as

693 coincident with the transgressive surface marking the base of the Chiwapa Sandstone, thus

694 making the lower Ripley beds Campanian. The dashed vertical arrow represents the uncertainty

695 of the exact stratigraphic position for the ceratopsid tooth within the Owl Creek Formation.

696

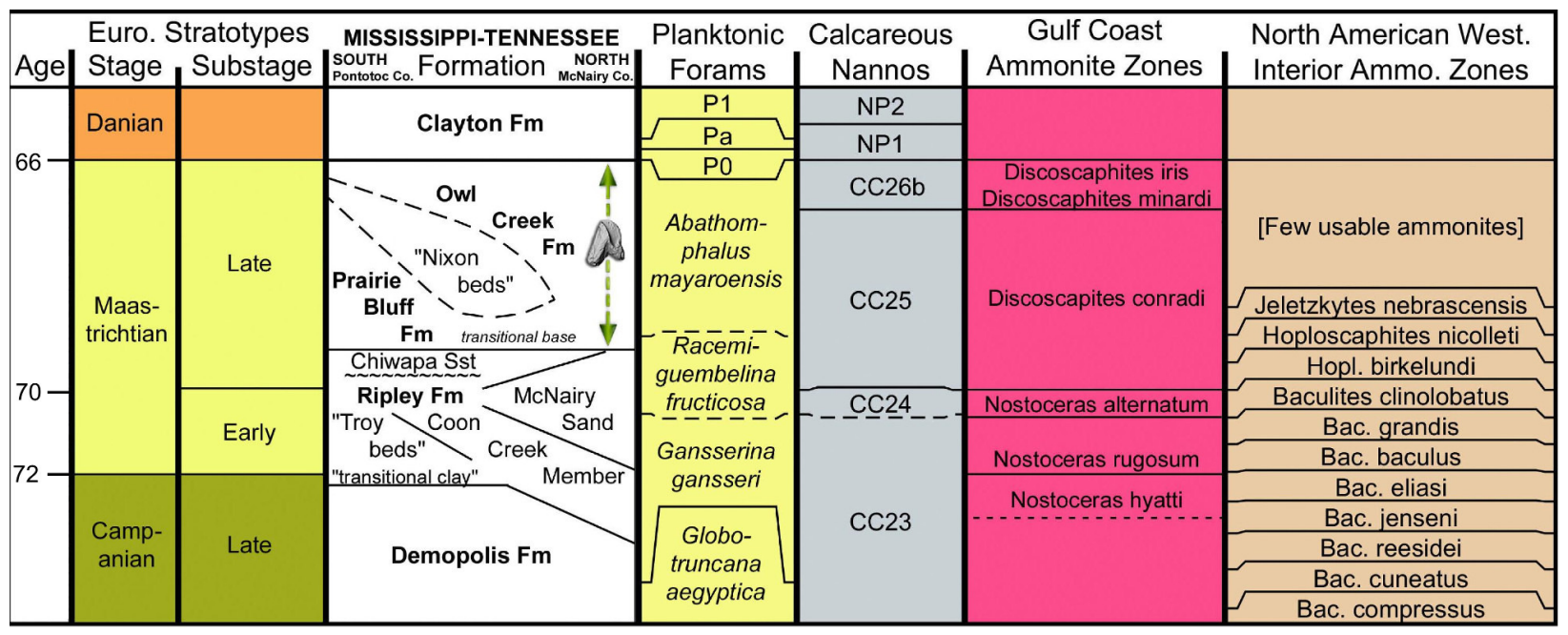


698 Figure 3. Marine macrofossils collected in loose association with ceratopsian tooth (from Table 699 1), most consistent with a Maastrichtian age. A) Striaticostatum cf. S. sparsum Sohl, MMNS IP700 8648; B) Liopistha protexta (Conrad), MMNS IP-6116; C) Discoscaphites iris (Conrad), 701 microconch, MMNS IP-8646; D) Costacopluma grayi Feldmann \& Portell, larger Maastrichtian 702 variety (Martínez-Díaz et al., 2016), MMNS IP-8647 (distinct from the smaller Danian variety); 703 E) Discoscaphites iris (Conrad), macroconch, MMNS IP-494; F) Cretalamna appendiculata 704 (Agassiz), variant of a lower posterior tooth, MMNS VP-8041; G) Branchiocarcinus flectus 705 (Rathbun), MMNS IP-6115.3; H) Mosasaurus hoffmani Mantell, MMNS VP-6803; I) Peritresius 706 707 ornatus (Leidy), costal carapace fragment, MMNS VP-4407.

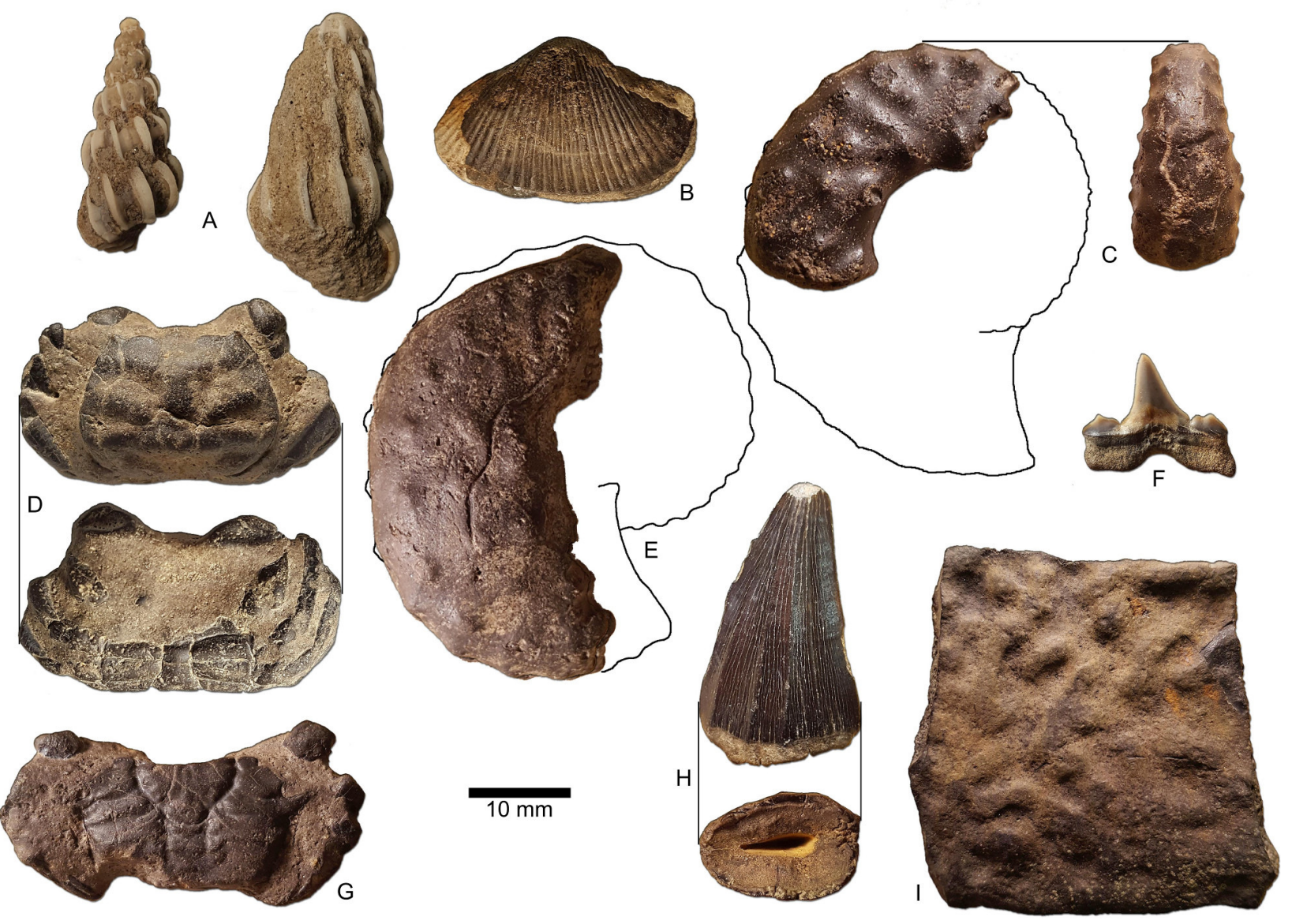


709 Figure 4. Paleogeographic maps of two key geochronologic intervals in the uppermost

710 Cretaceous of North America. Late Campanian (left) and late Maastrichtian (right) time slices

711 are depicted with southern Laramidia ceratopsid localities on the appropriate time interval map.

712 Ceratopsid occurrences and their associated ages are taken from numerous references (Lehman,

713 1996; Sullivan, Boere \& Lucas, 2005; Loewen et al., 2010; Sampson et al., 2010, 2013; Sullivan

714 \& Lucas, 2010; Porras-Múzquiz \& Lehman, 2011; Wick \& Lehman, 2013; Rivera-Sylva,

715 Hedrick \& Dodson, 2016; Lehman, Wick \& Barnes, 2016). Arrows designate late Maastrichtian

716 dispersal of ceratopsians, in this interpretation, along an emerging southern route formed by a

717 northerly retreating seaway. We note, however, that the exact placement of any subaerial

718 connection is uncertain (Berry, in press; Boyd \& Lillegraven, 2011; Slattery et al., 2015).

719 Although the exact identity of the Mississippi tooth is unknown, we have illustrated only

720 chasmosaurine silhouettes on this part of the figure because no centrosaurines are known from

721 North America during the late Maastrichtian. This Mississippi Embayment is labeled as "Miss.

722 Emb.”. Maps are part of the Key Time Slices of North America series, C 2013 Colorado Plateau

723 Geosystems, Inc., and used with their kind permission by licensed agreement. Silhouettes are by

724 Raven Amos (chasmosaurine) and Lukas Panzarin (centrosaurine, from Sampson et al., 2013),

725 via www.phylopic.org.

726

727
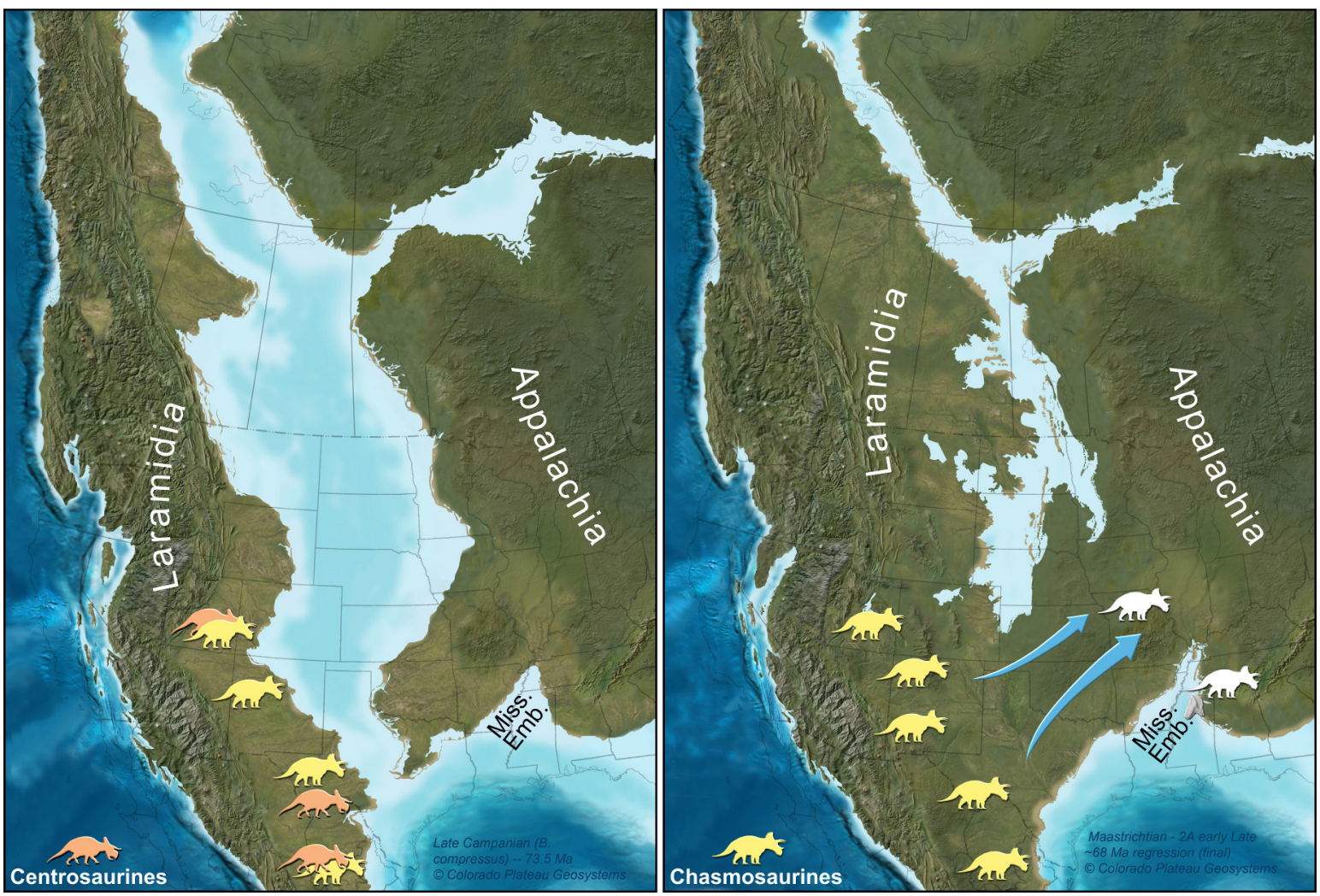
728 Figure 5. Right dentary tooth of ceratopsid dinosaur, MMNS VP-7969. Digital renderings and photographs in A, B) mesial (posterior); C, D) lingual (medial); E, F) distal (anterior); G, H) 730 apical (dorsal); I, J) labial (lateral); K, L) root (ventral) views. Scale bar equals $10 \mathrm{~mm}$.

731 Directional abbreviations: api, apical; dist, distal; mes, mesial; lab, labial; ling, lingual.
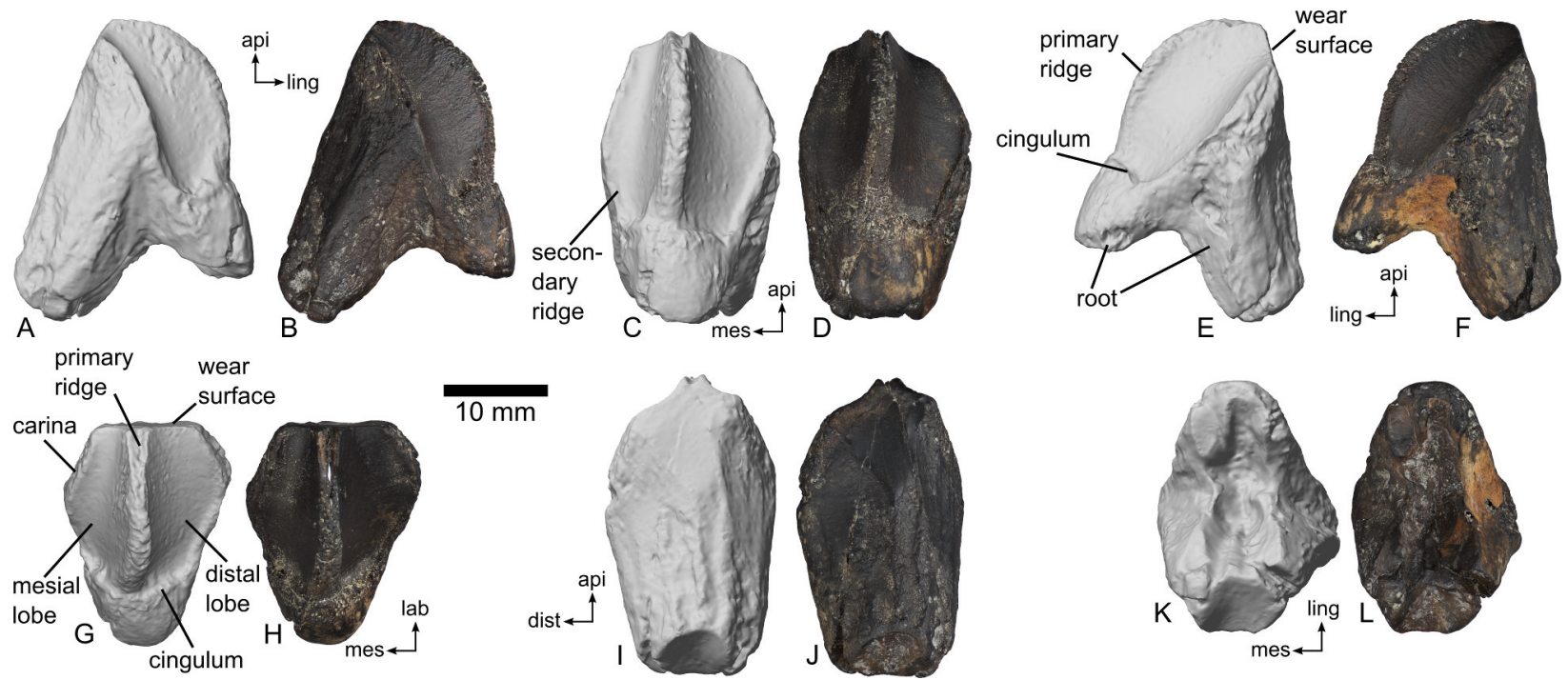
734 Table 1. Partial faunal list produced from Upper Cretaceous marine fossils collected in loose

735

736

737

738

739

740

741

742

743

744

745

746

747

748

749

750

751

752

753

754

755

756

757

758

759

760

761

762

763

764

765

766

767

768

769

770

771

772

773

774

775

776

777

778

779 association with MMNS VP-7969. The mollusks were previously established as characteristic of the late Maastrichtian Owl Creek Formation at the type locality, Tippah County, as well as historic outcrops in the vicinity of the ceratopsian locality, Union County (Sohl \& Koch, 1983). Many of the other listed species have also been previously reported as distinguishing Maastrichtian marine deposits of the eastern United States (e.g., Baird, 1986; Phillips, Nyborg \& Vega, 2014; Martínez-Díaz et al., 2016). Selected specimens are illustrated in Figure 3.

*Mollusks represented by original calcitic shell. Remaining macroinvertebrates are largely internal molds.

Mollusca

Bivalvia

Cucullaea capax Conrad, 1858

Tenuipteria argentea (Conrad, 1858)

Pinna cf. P. laquata Conrad, 1858

Exogyra costata Say, $1820 *$

Pycnodonte vesicularis Lamarck, 1806*

Pterotrigonia cf. P. eufalensis (Gabb, 1860)

Pterotrigonia sp.

Crassatella sp.

Linearia cf. L. metastriata Conrad, 1860

Eufistulana ripleyana (Stephenson, 1941)

Liopistha protexta (Conrad, 1853)

Gastropoda

Turritella $\mathrm{sp}(\mathrm{p})$.

Striaticostatum cf. S. sparsum Sohl, 1964*

Cephalopoda

Discoscaphites iris (Conrad, 1858)

Trachyscaphites sp.

Eubaculites carinatus (Morton, 1834)

Crustacea

Decapoda

Branchiocarcinus flectus (Rathbun, 1926)

Costacopluma grayi Feldmann \& Portell, 2007

Palaeoxanthopsis libertiensis (Bishop, 1986)

Vertebrata

Chimaeriformes

Ischyodus sp.

Selachii

Cretalamna appendiculata (Agassiz, 1843)

Squalicorax pristodontus (Agassiz, 1843)

Testudines

Peritresius ornatus (Leidy, 1856)

Squamata 
